\title{
How Does Increased Eutrophication and Pollution in the Lake Victoria Waters Impacts Zooplankton?
}

\author{
Godfrey William Ngupula \\ Tanzania Fisheries Research Institute (TAFIRI), PO Box 475, Mwanza, Tanzania \\ Tel: 255-762-835-412Ｅ-mail:ngupula@yahoo.co.uk/godfreyngupula@gmail.com
}

Received: October 21, 2013 Accepted: November 15, 2013 Published: December 25, 2013

doi:10.5296/jee.v4i2.4397ＵRL: http://dx.doi.org/10.5296/jee.v4i2.4397

\begin{abstract}
To understand how eutrophication and pollution impacts zooplankton in the Lake Victoria waters, zooplankton samples were collected during a 21 days survey conducted from $6^{\text {th }}$ to $27^{\text {th }}$ May, 2013 constituting a total of 71 sampling stations. A net of $60 \mu \mathrm{m}$ nitex mesh was used for the purpose. The lake waters were categorized into six ecological zones with the understanding that, inshore waters are the most highly impacted as compared to nearby and far offshore. Comparing to the data collected in 2007, it can be concluded that zooplankton have decreased in abundance. The inshore waters indicated the highest abundance contrasting the far offshore. Cyclopoids dominated other zooplankton by $73 \%$ and were evenly distributed in all the waters while calanoids (18\%) increased towards offshore locations. Rotifers were the least in abundance (4\%), after cladocerans (5\%) and were confined in the inshore waters. In regards to the fact that calanoids and cladocerans dominated the Victoria waters during 1930s and the fact that predation forces from zooplantivores fish (like Rastrineobola argentea Pellegrin 1904 (dagaa), haplochromines, and juveniles of Nile perch (Lates niloticus, L.)) are not responsible for the reversed situation, then the findings imply that increased eutrophication and pollution impacts the lake zooplankton by favouring the increase of cyclopoids and some species of rotifers while limiting the calanoids and cladocerans to mainly offshore locations. The current observed low abundance of zooplankton does not threaten the pelagic fishery of the lake.
\end{abstract}

Keywords: Abundance, Calanoid, Cyclopoid, Haplochromines, Rotifer 


\section{Introduction}

The quality of water in Lake Victoria (the largest in Africa and the second largest in the world) ecosystem has been deteriorating fast, due to mainly increased disturbances in its catchments (Sitoki et al., 2010; Ngupula et al., 2012). The impacts of the observed deterioration have been observed mostly on changed composition and abundance of plankton and benthic macroinvertebrates, leading into dominance of robust and less important species. For example, phytoplankton community of the lake is dominated by the less important Bacillariophytes (i.e. Nitzschia acicularis (Kütz.) W. Smith and Lyngbya circumcreta G.S West) and Cyanobacteria (Microcystis flos aquae (Wittrock) Kirchner) (Kling et al., 2001; Ngupula et al., 2011). The zooplankton community is currently dominated by small sized cyclopoids contrasting the past situation where large sized calanoids and cladocerans dominated (Mavuti and Litterick, 1991; Mwebaza-Ndawula, 1994; Gophen et al., 1995; Ngupula et al., 2010). Benthic macroinvertebrates have increased in abundance and is dominated by gastropods and bivalves in favour of the insects and worms (Mbahinzireki, 1994; Muli and Mavuti, 2001; Ngupula and Kayanda, 2010). Possibly, the observed impacts have magnified to the vertebrates' composition and abundance too. For example, when compared to the situation before 1990s, there is a decline in abundance of important commercial fish while many native fish have almost disappeared (Ogutu-Ohwayo, 1990a, b; Kayanda et al., 2009, Kishe-Machumu et al., 2008; 2011).

In most aquatic ecosystems, zooplanktons are appreciated as important for the role they play in the energy flow by linking the primary productions to secondary and tertiary productions. In Lake Victoria, the appreciated zooplanktivores fish include most reappearing haplochloromines, Rastrineobola argentea Pellegrin, 1904 (Dagaa), and juveniles of Nile perch (Lates niloticus L.) (Wanink, 1998; Wanink et al., 2002; Tumwebaze et al., 2007; Kishe-Machumu et al., 2008; 2011). Currently, as stocks of Nile perch and Nile tilapia (Oreochromis niloticus, L.) are declining, the stocks of dagaa have been increasing exponentially, and thus form an important fishery of the lake, second to Nile perch (Tumwebaze et al., 2007; Kayanda et al., 2009). In this lake, dagaa (named as Mukene in Uganda and Omena in Kenya) has been caught in high abundance to quench the demand for local markets and also transported to some countries like Congo, Zambia, Malawi, Rwanda, and Burundi. In fact, dagaa is the most consumed fish by many people in East Africa, especially Tanzania as Nile perch fish is unavailable in the local markets (considered as fish for export) and Nile tilapia has highly declined.

Generally, Lake Victoria is regarded as eutrophied and polluted; however the intensity of the impact differs depending on time and space. For example, inshore waters (i.e. most bays and gulfs) are most highly impacted as compared to nearby and far offshore waters (Ngupula et al., 2012). In this regard, it is quite probable that there are some observable impacts on the zooplankton of the lake of which have not been stipulated. And, it is possible that those effects are magnified to its predators (i.e. dagaa) thus dictating their dynamics over the year. Considering the fact that dagaa constitutes the important fishery of the lake and it is the only fish that is cheaply available as a source of protein to many, it is worthy understanding some aspects that may dictate its dynamics. In the history of the Lake Victoria researches, studies 


\section{Macrothink}

that cover some aspects of its zooplankton are quite few. And, as regards to Tanzanian waters (51\%) of the lake, the situation is much worse. This study therefore quantifies the abundance, composition, and distribution of zooplankton in the various ecological zones of the lake and discusses the findings in relation to water quality and projects on the sustainability of dagaa fishery. This study's main hypothesis is: eutrophication and pollution in the lake waters negatively impacts its zooplankton.

\section{Materials and Methods}

\subsection{Study Area and Characterization of Site}

This study was undertaken in the Tanzanian waters of Lake Victoria which comprise an area of $35,088 \mathrm{~km}^{2}$ out of $68,800 \mathrm{~km}^{2}$ of total lake area. Zooplankton samples were collected during a 21 days survey conducted from $6^{\text {th }}$ to $27^{\text {th }}$ May 2013 constituting a total of 71 sampling stations (Figure 1).

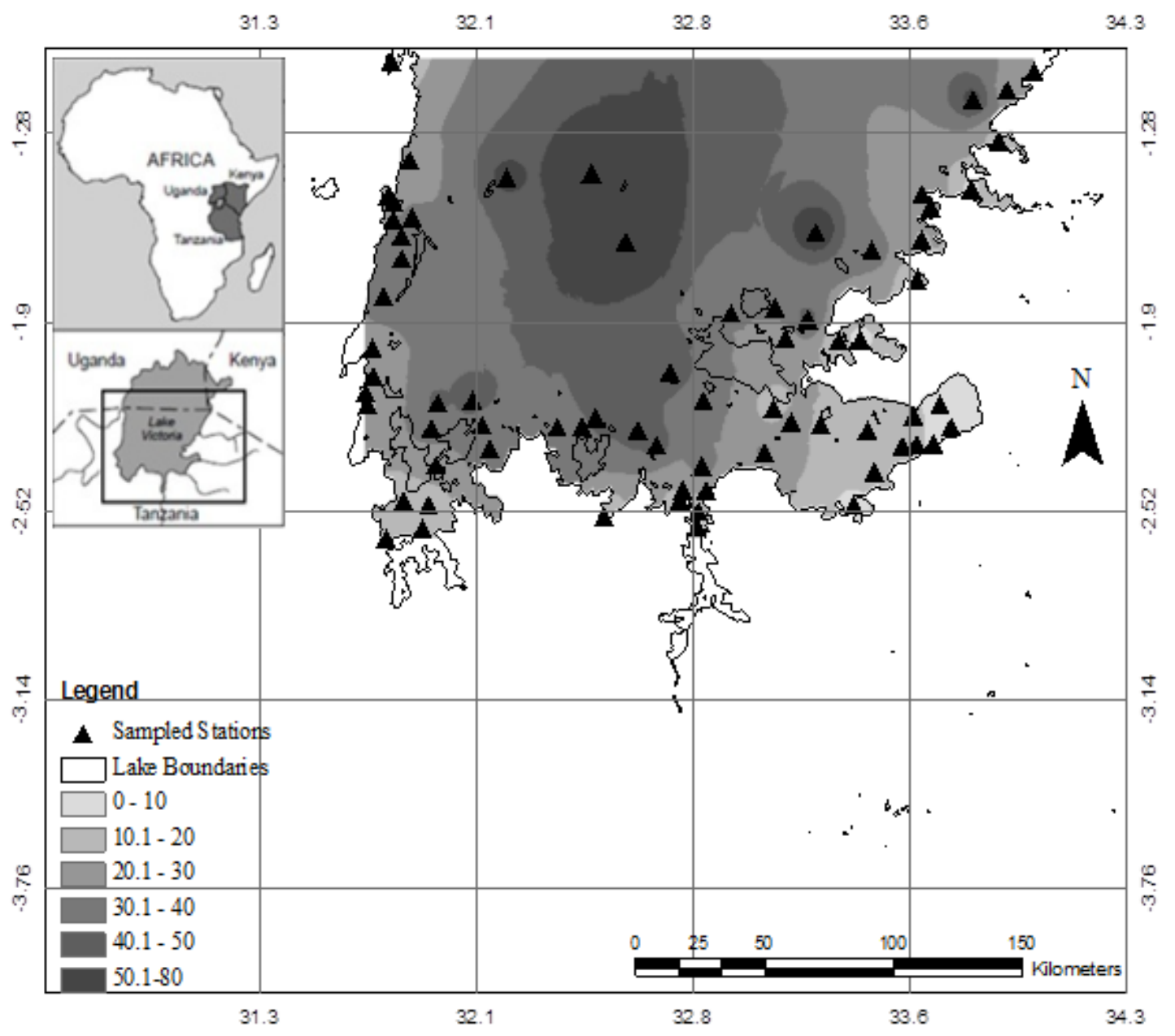

Figure 1. Distribution of sampling stations (71) in the Lake Victoria (Tanzanian waters) and illustration of depth strata

Influenced by the climate of Lake Victoria basin region, the Lake Victoria normally 
experiences two sub periods and two important periods: (a) the start of the lake mixing (partial break of thermocline) during moderate wet and cold June (b) fully lake mixing period during a dry and windy season in July to September (c) lake thermal reestablishment and moderate stratification during short rains of October to December (d) lake fully stratification during the long rains of March to May. This study was undertaken when the lake was fully stratified.

Assuming that the waters of the lake are differently impacted by what is happening in its catchments, the implementation of Fisheries Management Plan (IFMP) of the Lake Victoria, to harmonize the research activities of the riparian countries bordering the lake, decided to divide it into six depth strata. Thus resulting into three main ecological zones, namely shallow nearshore (strata I and II) waters, intermediate (strata III and IV), and deep offshore (strata V and VI) waters. Depth Stratum I was 0-10 m deep and Stratum II was 10.1-20 m deep. Stratum III was 20.1-30 m deep and Stratum IV was 30.1-40 m deep. Stratum V was 40.1-50 m deep and Stratum VI was >50 m deep (Ngupula et al., 2011).

\subsection{Sampling Strategy and Analysis of Samples}

Triplicate samples of zooplankton were collected by vertically hauling $60 \mu \mathrm{m}$ mesh size (30 $\mathrm{cm}$ mouth opening and one meter length) plankton net from one meter above the lake's bottom to the surface. The samples were preserved with $4 \%$ formaldehyde inboard the vessel for later laboratory analyses. In the laboratory, the samples were washed with water to remove the formalin, and then diluted to $100 \mathrm{mls}$ of which $10 \mathrm{mls}$ were subsampled for counting using an inverted microscope at $\mathrm{x} 40$ magnification. The zooplankton was identified using keys and manuals as given by Ruttner-Kolisko (1974), Korinek (1984), Maas (1993), and Korovchinsky (1993). The sex differentiation was not considered in this study and only adults were counted. The count data (number/subsample) were taken in a computer for analysis of organisms as individuals per cubic meter of water and as individuals in a given one liter of water. For example: (i) Number/sample $=$ Dil $^{\mathrm{n}}{ }^{\mathrm{vol}}{ }^{*}$ number in a sub-sample* ${ }^{*}$ split factor $\div$ count volume. (ii) Number $/ \mathrm{m}^{2}=$ number $/$ sample $\div$ Area of net mouth opening in $\mathrm{m}^{2}$. For a net of $30 \mathrm{~cm}$ opening, Area $=0.0855 \mathrm{~m}^{2} \quad$ (iii) Number $/ \mathrm{m}^{3}=$ number $/ \mathrm{m}^{2} \div$ Depth of tows in meters (total depth of the sampling site - one meter) (iv) Number/1 = number $/ \mathrm{m}^{3} / 1000$. The used formulas are as given by the Implementation of Fisheries Management Plan (IFMP) manuals for limnological studies. The abundance of zooplankton was expressed as individuals in a litre of water. To safeguard future references, each counted sample was returned to its original and fixed with $40 \%$ formaldehyde and $70 \%$ alcohol and stored.

Parallel with sampling zooplankton, conductivity, dissolved oxygen (DO), temperature, and turbidity were also measured using a CTD device (Seabird Electronics model SBE 19) and measurements were averaged over the water column.

\subsection{Statistical Analysis}

One-Way ANOVA (with Tukey HSD test for multiple comparisons) was used for the test of spatial variation of zooplankton abundances and environmental parameters. The statistical 
tests were as given by SPSS (Version 17, USA) statistical package.

\section{Results}

Cyclopoid copepods dominated the zooplankton community by $73 \%$ of the total zooplankton and were uniformly distributed in all the waters. The abundance of calanoid copepods $(18 \%)$ increased towards offshore locations. The abundance of cladocerans (5\%), which followed after that of cyclopoids and calanoids indicated no trend with water depth. The least in abundance, the rotifers (4\%) indicated a decreasing trend towards offshore locations (Figure 2 and 3).

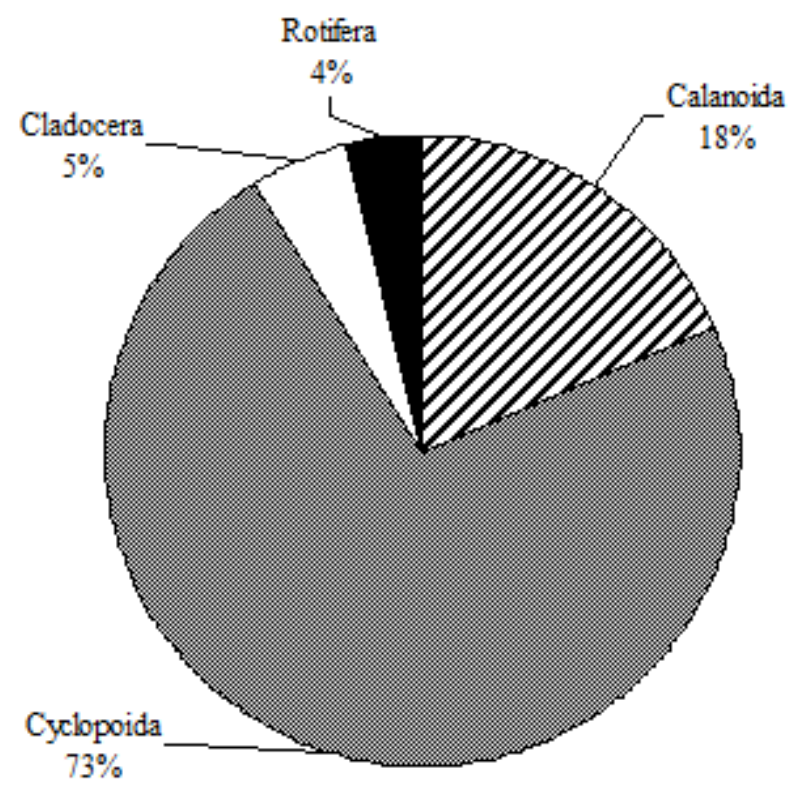

Figure 2. Percentage composition of zooplankton taxa in the Tanzanian waters of Lake Victoria 


\section{Macrothink $\Delta$ Institute ${ }^{\text {tM }}$}
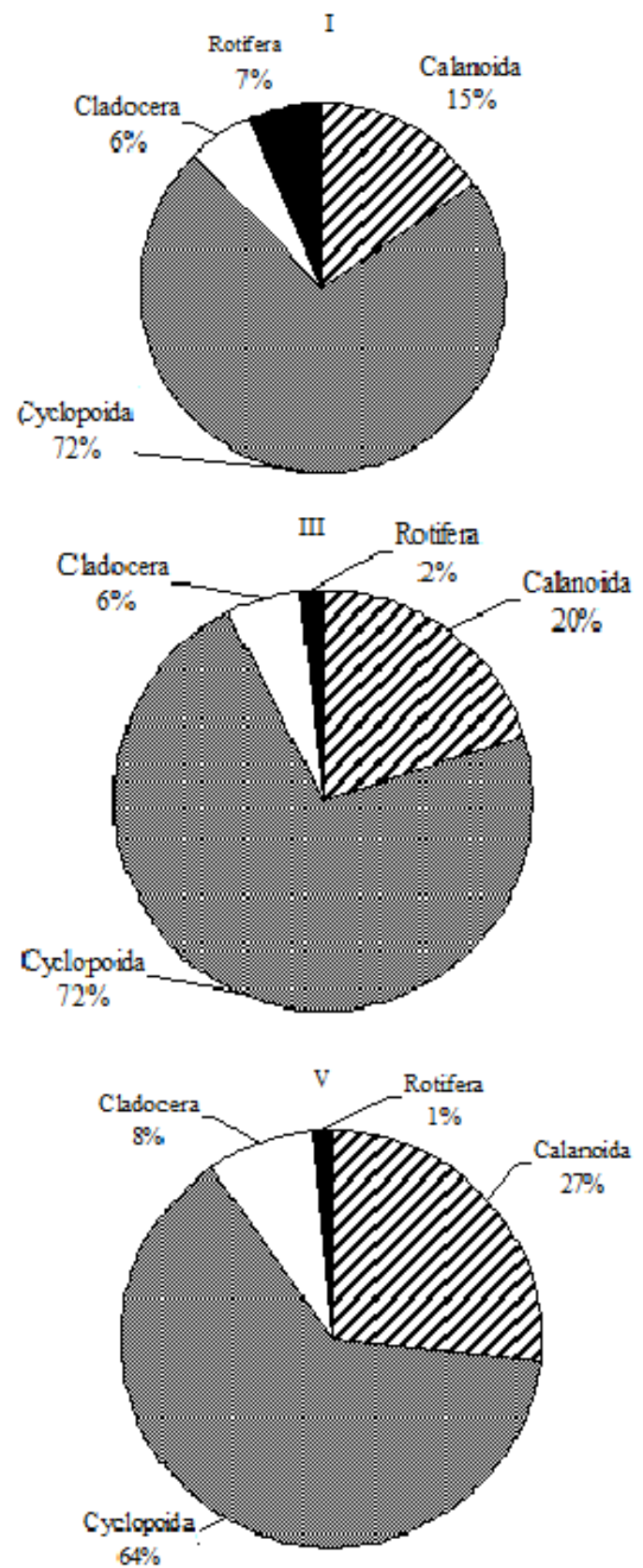

Journal of Environment and Ecology

ISSN 2157-6092

2013, Vol. 4, No. 2
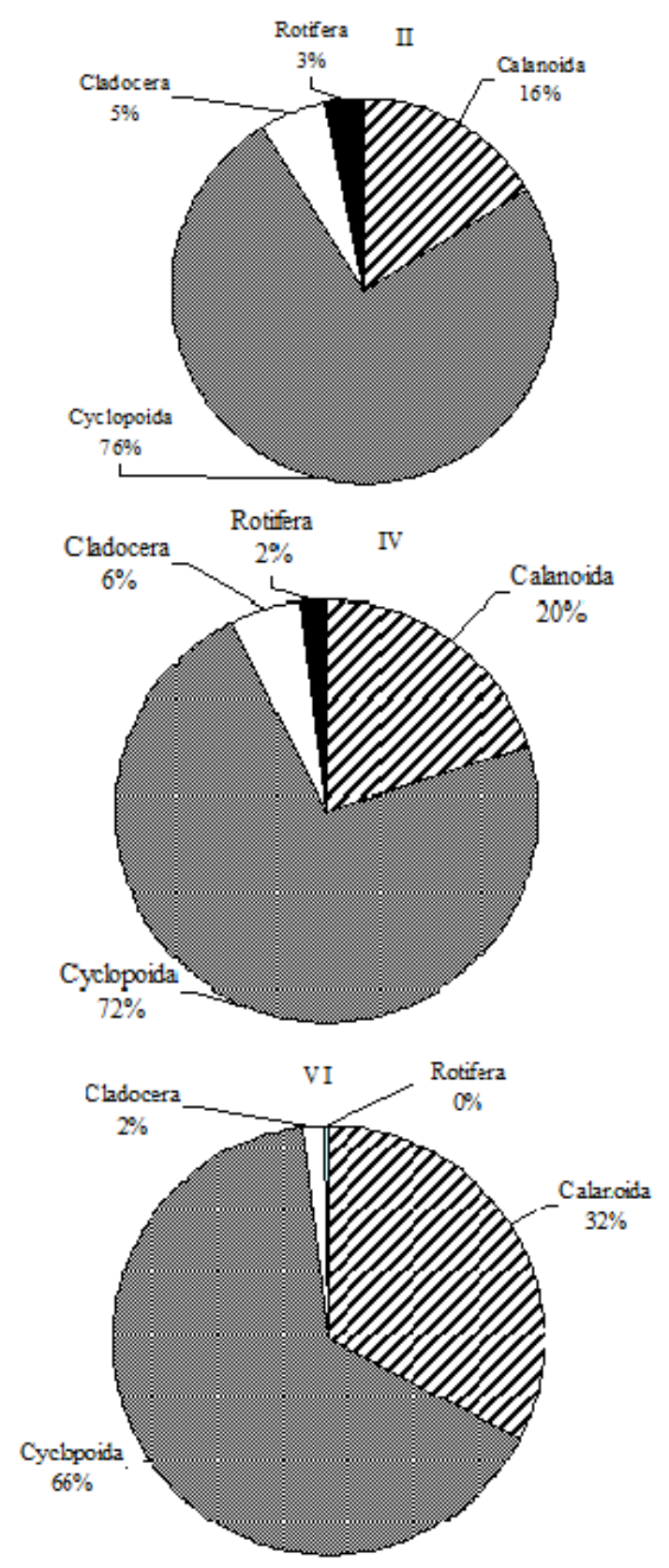

Figure 3. Percentage composition of zooplankton taxa in the different depth strata (I-VI) of the Tanzanian waters of Lake Victoria.

Zooplankton abundance indicated a decreasing trend with depth strata. Depth stratum I had highest abundance $\left(5.39 \pm 4.23\right.$ ind $\left.^{-1}\right)$ while depth stratum VI had the lowest $(0.79 \pm 0.64$ ind. $1^{-1}$ ) (Figure 4). The One-Way ANOVA test for significance in differences of means of the different depth strata, returned insignificant results (tested on different zooplankton groups across all strata, $\mathrm{F}=1.65, \mathrm{p}=0.153$ ). 


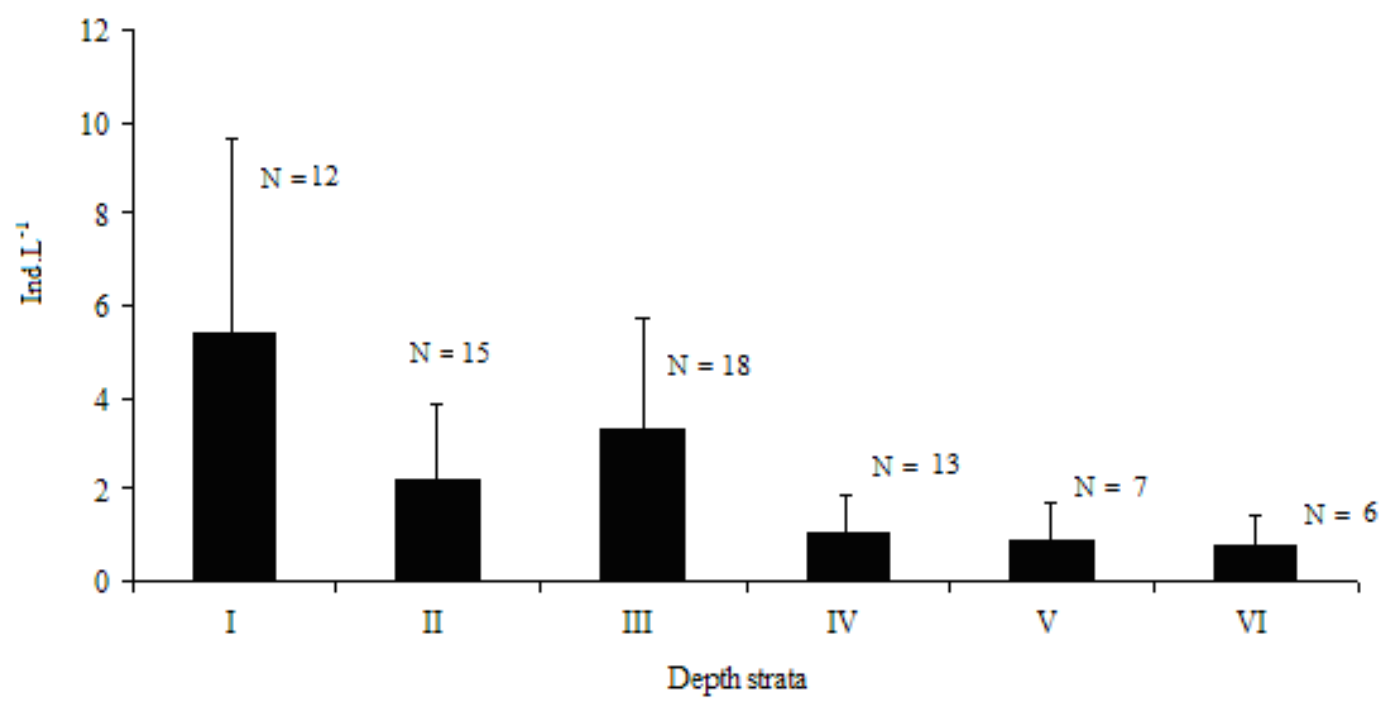

Figure 4. Average abundances of zooplankton in different depth strata of the Lake Victoria, Tanzanian waters. Error bars represent SD

A total of 36 zooplankton species (or taxa) were encountered (Table 1); of those 16 species were rotifers, with Brachionus angularis Gosse 1851 and Brachionus caudatus Barrois \& Daday 1894 as the most abundant. There were 12 taxa of Cladocerans, with Diaphanosoma excisum Sars 1885 and Bosmina longirostris Müller 1885 as the most abundant. There were 7 cyclopoid taxa with Thermocyclops emini Mrazek 1895, Tropocyclops tenellus Sars 1909, and Thermocyclops neglectus Sars 1909 as the most abundant. There was only one calanoid taxon, Thermodiaptomus galeboides Sars 1901.

Table 1. Abundances (ind. $\mathrm{m}^{-3}$ ) of zooplankton species in the various depth strata of Lake Victoria (Tanzania waters), recorded in May 2013. $0=$ Absent.

\begin{tabular}{|l|l|l|l|l|l|l|l|}
\hline Stratum & & I & II & III & IV & V & VI \\
\hline Calanoida & & & & & & & \\
\hline Thermodiaptomus galeboides & Sars 1901 & 2614 & 1064 & 1746 & 651 & 880 & 834 \\
\hline Cyclopoida & & & & & & & \\
\hline $\begin{array}{l}\text { Mesocyclops sp. } \\
\text { Eucyclops spp. }\end{array}$ & & 581 & 224 & 495 & 21 & 118 & 32 \\
\hline Thermocyclops emini Mrazek 1895 & 326 & 156 & 151 & 121 & 108 & 40 \\
\hline Thermocyclops incisus Kiefer 1932 & 3131 & 1212 & 1750 & 487 & 354 & 492 \\
\hline Thermocyclops neglectus Sars 1909 & 376 & 162 & 398 & 21 & 21 & 17 \\
\hline Tropocyclops confinnis Kiefer 1929 & 3185 & 878 & 1254 & 445 & 615 & 331 \\
\hline Tropocyclops tenellus Sars 1909 & 1780 & 853 & 1523 & 401 & 207 & 144 \\
\hline Cladocera & 2859 & 1448 & 1677 & 855 & 667 & 636 \\
\hline
\end{tabular}




\section{Macrothink}

\begin{tabular}{|l|l|l|l|l|l|l|}
\hline Alona sp. & 47 & 10 & 0 & 11 & 0 & 0 \\
\hline Bosmina longirostris Müller 1885 & 78 & 32 & 58 & 54 & 102 & 17 \\
\hline Ceriodaphnia cornuta Sars 1885 & 20 & 0 & 0 & 16 & 23 & 3 \\
\hline Chydoridae spp. & 153 & 11 & 0 & 0 & 0 & 3 \\
\hline Daphnia lumholtzi (helmeted) Sars 1885 & 211 & 28 & 13 & 23 & 35 & 12 \\
\hline Daphnia barbata Weltner 1898 & 39 & 0 & 7 & 0 & 4 & 0 \\
\hline Diaphanosoma excisum Sars 1885 & 156 & 119 & 79 & 25 & 75 & 3 \\
\hline Macrothrix sp. Baird 1843 & 0 & 35 & 82 & 5 & 4 & 6 \\
\hline Moina micrura Kürz,1874 & 131 & 82 & 47 & 53 & 27 & 0 \\
\hline Chirocephalus diaphanus Prevost 1803 & 70 & 44 & 0 & 0 & 0 & 0 \\
\hline Moina hutchinsoni Brehm 1937 & 19 & 0 & 0 & 0 & 0 & 0 \\
\hline Ceriodaphnia reticulata Juline1820 & 39 & 0 & 0 & 0 & 0 & 0 \\
\hline Rotifera & & & & & & \\
\hline Ascomorpha sp. & 0 & 0 & 15 & 0 & 4 & 0 \\
\hline Asplanchna spp. & 0 & 0 & 31 & 0 & 12 & 0 \\
\hline Asplanchna sieboldi Leydig 1854 & 0 & 0 & 16 & 0 & 0 & 0 \\
\hline Brachionus angularis Gosse 1851 & 231 & 0 & 50 & 0 & 12 & 3 \\
\hline Brachionus calyciflorus Pallas 1776 & 92 & 0 & 8 & 0 & 0 & 0 \\
\hline Brachionus caudatus Barrois \& Daday 1894 & 256 & 0 & 8 & 0 & 0 & 0 \\
\hline Brachionus falcatus Zacharias 1898 & 22 & 0 & 0 & 0 & 0 & 0 \\
\hline Brachionus patulus Müller 1786 & 139 & 0 & 0 & 0 & 0 & 0 \\
\hline Filinia longiseta Ehrenberg 1898 & 19 & 0 & 0 & 0 & 0 & 0 \\
\hline Keratella tropica Apstein 1907 & 0 & 0 & 0 & 5 & 8 & 3 \\
\hline Keratella cochlearis Gosse 1851 & 45 & 0 & 0 & 0 & 4 & 0 \\
\hline Keratella quadrata Müller 1786 & 22 & 0 & 0 & 0 & 0 & 0 \\
\hline Lecane bulla Gosse 1851 & 0 & 0 & 8 & 5 & 0 & 3 \\
\hline Polyarthra vulgaris Carlin 1943 & 0 & 0 & 7 & 0 & 0 & 0 \\
\hline Polyarthra spp. & 0 & 0 & 8 & 0 & 0 & 0 \\
\hline Trichocerca spp. & 0 & 0 & 13 & 0 & 0 & 0 \\
\hline
\end{tabular}

The measured physical and chemical parameters indicated a declining trend with depth, implying that depth stratum I had highest values of conductivity, dissolved oxygen (DO), temperature, and turbidity. While conductivity indicated a range (Mean $\pm \mathrm{SD}$, depth stratum I to depth stratum VI) of $107.20 \pm 0.56$ to $95.52 \pm 0.79 \mu \mathrm{S} / \mathrm{cm}$, DO indicated a range of $6.27 \pm$ 0.18 to $4.91 \pm 0.49 \mathrm{mgl}^{-1}$. Temperature indicated a range of $25.36 \pm 0.35^{\circ} \mathrm{C}$ to $25.22 \pm 0.49{ }^{\circ} \mathrm{C}$ and turbidity indicated a range of $5.592048 \pm 0.262766$ to $1.36 \pm 0.14 \mathrm{NTU}$ (Figure 5). The One -Way ANOVA for the test of significance in spatial variations of the physical-chemical parameters indicated significant results $(\mathrm{F}=2005.36 . \mathrm{DF}=23, \mathrm{p}<0.001)$. 


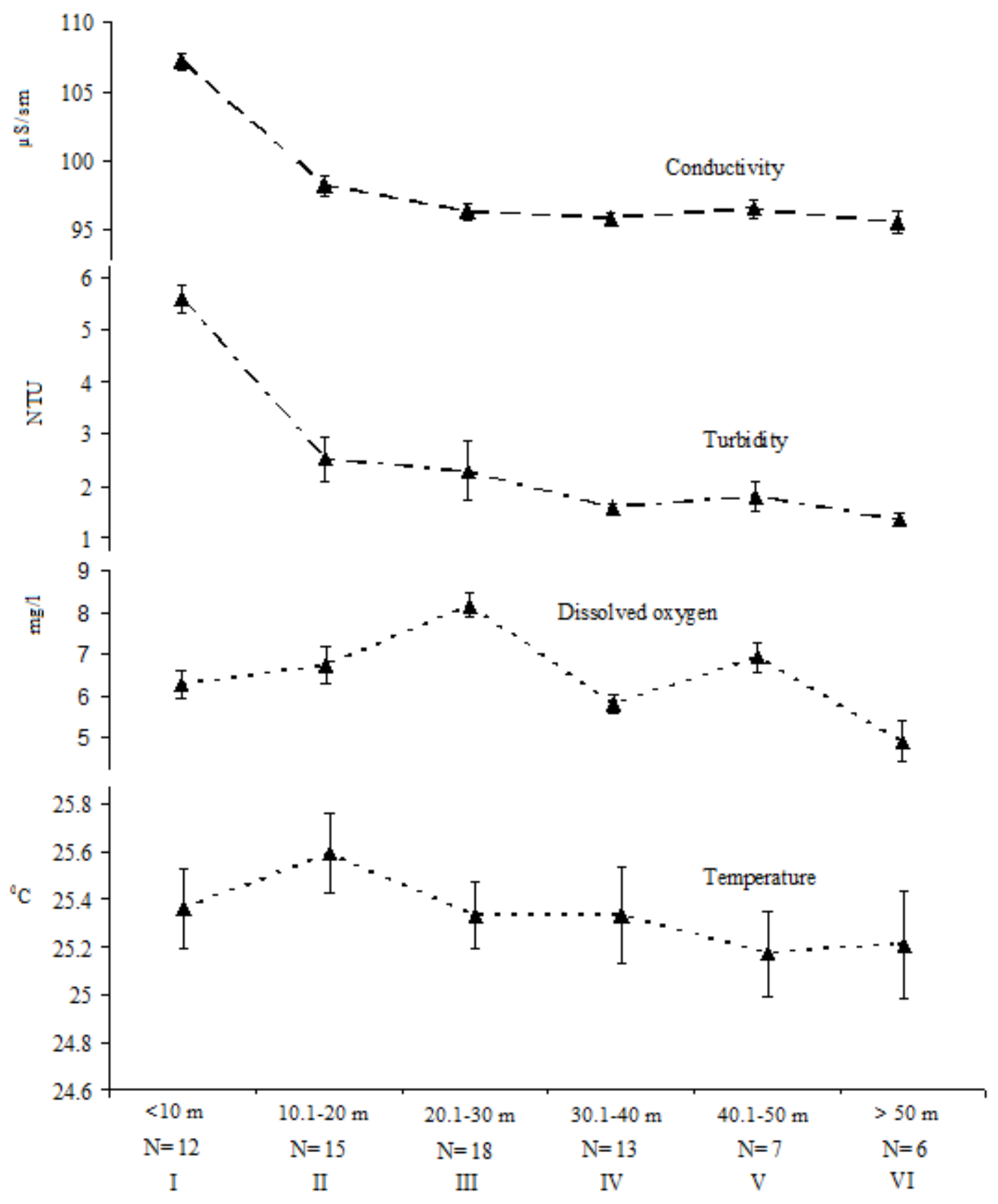

Figure 5. Average values of conductivity, turbidity, dissolved oxygen, and temperature in different depth strata (I-VI) of the Lake Victoria, Tanzanian waters. Error bars represent SD

\section{Discussion}

The results of this study indicate that cyclopoid copepods were the highest in abundance and corroborates with the studies by Rzoska (1956), Mavuti and Litterick (1991), Mwebaza-Ndawula (1994), and Ngupula et al., 2010. However, contrast with that by Worthington (1931) who found the dominance of large bodied calanoids and cladocerans in the lake zooplankton community contrasting the current situation. The observed change can be attributed to the increased eutrophication and pollution in the lake waters. This fact is 
probably true as calanoids and cladocerans of the Lake Victoria are somehow successful in the offshore waters which are less eutrophicated and polluted as compared to shallow nearshore waters (Ngupula et al., 2010, 2012). Sometimes ago it was thought that probably there was a selective predation preference by most zooplanktivore fish of the lake (i.e. $R$. argentea, haplochromines, and juveniles of Nile perch) for calanoids and cladocerans, the force that provided cyclopoids a predation relief (Gophen et al., 1995). However, according to Wanink et al., (2002), the said zooplanktivores fish do not have any significant preferences towards big sized calanoids and cladocerans, implying that other forces an outcome of the increased degraded quality of the lake waters contribute importantly in shaping the zooplankton community.

Cyclopoids were evenly distributed in all the waters. Our finding corroborates with the studies by Ngupula et al., (2010) and contrast with the studies by Rzoska (1956), Mavuti and Litterick (1991), and Mwebaza-Ndawula (1994) who found that cyclopoids were successful mostly in the offshore waters. Ngupula et al., (2010) attributed the high success of cyclopoids with its exceptional tolerance to a range of environmental conditions (Mavuti and Litterick, 1991) and with its grazing as well as its predatory behaviors (i.e. Mesocyclops sp.) (Waya and Mwambungu, 2004). This study supports that line of reasoning. The success of rotifers in the inshore waters of the lake (as indicated by this study) could also help show how eutrophication and pollution shape the zooplankton community as rotifers are known to flourish well in polluted and eutrofied waters (Mavuti and Litterick, 1991; Ngupula et al., 2010).

As compared to the situation in 2007 (the last quantification of zooplankton in the Tanzanian waters), the current abundance of zooplankton in the lake waters has decreased. The observed decrease can be attributed to the increased abundances of zooplanktivores fish in the lake (Kishe-Machumu et al., 2008; 2011). This is probably true as the current catches of many of the resurging haplochromines and dagaa have increased, and the current population of Nile perch is dominated by mostly juveniles (Katunzi et al., 2006; Kayanda et al., 2009). For example, dagaa catches has increased in such the fish is considered as second to Nile perch in terms of its commercial importance (Kayanda et al., 2009; Tumwebaze et al., 2007). Despite the fact that dagaa fishery in the lake follows moon phases, but the fishery itself has some dynamics. For example, dagaa usually are caught in highest abundance during the lake mixing and rainy (warm) periods (Nsinda et al., 2012). Seasonal effects on dagaa are also observed in its mean sizes and maturity stages (Nsinda et al., 2012). In this regard, it is quite probable that changes in zooplankton abundance over time have some connections with the dagaa abundances in the lake.

Depth stratum I (inshore waters) had highest abundance of zooplankton. This finding contrast with that of Ngupula et al., 2010 which indicated that intermediate waters had highest abundance as compared to nearshore and deep offshore waters. Our finding agrees with other African Great Lakes studies in which most of the species richness in these lakes was confined in the nearshore regions (Moss, 1998). The observed highest success of zooplankton (mostly cyclopoids and rotifers) in the nearshore waters implies high adaptability to poor environmental conditions as nearshore are the most polluted (i.e. highly turbid) and eutrofied 
(with abundant phytoplankton blooms) (Mavuti and Litterick, 1991; Mugide et al., 2003; Ngupula et al., 2012).

This study encountered 7 cyclopoid taxa with T. emini, T.tenellus, and T. neglectus as the most abundant. The finding concurs with the studies by Mavuti and Litterick (1991) and Ngupula et al. (2010) who found T. emini, T. neglectus and T. tenellus as the most abundant species. This study suspects that there some cases where there is occasional discrepancies in the identification of zooplankton species in the Lake Victoria region mainly due to inadequacy of the identification keys used. There is, thus, a need for a full description of the lake's fauna, especially copepods, as the use of identification keys from other regions may lead to erroneous identification.

We used a net of $60 \mu \mathrm{m}$ to quantify zooplankton in the lake. Generally, it is appreciated that zooplankton are obtained wherever a net of $30 \mu \mathrm{m}$ and above is used properly. So far, most unpublished and published studies that have quantified zooplankton in the lake have used nets with a range of $35 \mu \mathrm{m}-300 \mu \mathrm{m}$. Some examples of the published studies and the net used are as follows: Mavuti and Litterick, (1991):105 $\mu \mathrm{m}$, Mwebaza-Ndawula (1994):35-300 $\mu \mathrm{m}$, Waya and Mwambungu (2004): $65 \mu \mathrm{m}$, and Ngupula et al. (2010): $67 \mu \mathrm{m}$. I think, while sampling zooplankton, it is proper to use nets with varying sizes for increased efficiency as used by Mwebaza-Ndawula (1994):35-300 $\mu \mathrm{m}$. The probability of missing some big and high speed zooplankton when using a small net is high. And, the probability of missing some small zooplankton (like some rotifers) when using a big eyed net is high too.

\section{Conclusions}

The increased eutrophication and pollution in the Lake Victoria waters helps in shaping the zooplankton community by favouring the increase of cyclopoids and some species of rotifers while limiting the distribution of calanoids and cladocerans to only offshore locations. Predation forces from the highly abundance dagaa, juvenile perches, and reappearing haplochromines negatively impacts the abundance of zooplankton in the lake.

\section{Acknowledgements}

This work was sponsored by Trade and Agricultural Support Programme phase II (TASP II). We are grateful for the support extended by the TAFIRI staffs during data collection.

\section{References}

Gophen, M., Ochumba, P. B., \& Kaufman, L. S. (1995). Some aspects of perturbation in the structure and biodiversity of the ecosystem of Lake Victoria (East Africa). Aquatic Living Resources, 8(1), 27-41. http://dx.doi.org/10.1051/alr:1995003.

Kayanda. R, Taabu, A. M., Tumwebaze, R., Muhoozi, L., Jembe, T., Mlaponi, E, \& Nzungi, P. (2009). Status of the major commercial fish stocks and proposed species-specific management plans for Lake Victoria. African Journal of Tropical Hydrobiology and Fisheries, 12, 60- 66.

Katunzi, E. F. B., Van Densen, W. L. T., Wanink, J. H., \& Witte, F. (2006). Spatial and 
seasonal patterns in the feeding habits of juvenile Lates niloticus (L.), in the Mwanza Gulf of Lake Victoria. Hydrobiologia, 568(1), 121-133. http://dx.doi.org/10.1007/s10750-006-0033-3.

Kling, H. J, Mugidde, R, \& Hecky, R.E. (2001). Recent changes in the phytoplankton community of Lake Victoria in response to eutrophication. In: Munawar, M., Hecky, R.E. (eds), The Great Lakes of the World (GLOW): food-web, health and integrity (pp. 47-65). Leiden: Backhuys Publishers.

Kishe-Machumu, M. A, Witte, F, \& Wanink, J.H. (2008). Dietary shift in benthivorous cichlids after the ecological changes in Lake Victoria. Animal Biology, 58, 401-417. http://dx.doi.org/10.1163/157075608X383700.

Kishe-Machumu, M. A., Witte, F., Wanink, J. H., \& Katunzi, E. F.B. (2011). The diet of Nile perch, Lates niloticus (L.) after resurgence of haplochromine cichlids in the Mwanza Gulf of Lake Victoria. Hydrobiologia, 682(1), 111-119. http://dx.doi.org/10.1007/s10750-011-0822-1

Mavuti, K. M., \& Litterick, M. R. (1991). Composition, distribution and ecological role of zooplankton community in Lake Victoria, Kenya waters. Internationale Vereinigung fuer Theoretische und Angewandte Limnologie. Verhandlungen IVTLAP, 24(2), 1117-1122.

Mwebaza-Ndawula, L. (1994). Changes in relative abundance of zooplankton in northern Lake Victoria, East Africa. Hydrobiologia, 272, 259-264. http://dx.doi.org/10.1007/978-94-011-0884-3_19

Moss, B. (1998). Ecology of freshwaters, man and medium, past to future (3rd edn). Minneapolis: University of Minnesota Press.

Mugidde, R., Hecky, R.E., Hendzel, L.L., \& Taylor, W.D. (2003). Pelagic nitrogen fixation in Lake Victoria (East Africa). Journal of Great Lakes Research, 29(2), 76-88. http://dx.doi.org/10.1016/S0380-1330(03)70540-1

Muli, J. R., \& Mavuti, K. M. (2001). The benthic macrofauna community of Kenyan waters $\begin{array}{llll}\text { of Lake } \quad \text { Victoria. } & \text { Hydrobiologia, } & \text { 458(1-3), }\end{array}$ http://dx.doi.org/10.1023/A:1013184128681

Ngupula, G. W., \& Kayanda, R. (2010). Benthic macrofauna community composition, abundance and distribution in the Tanzanian and Ugandan inshore and offshore waters of Lake Victoria. African Journal of Aquatic Science, 35(2), 185-192. http://dx.doi.org/10.2989/16085914.2010.490978.

Ngupula, G. W., Waya, R. K., \& Ezekiel, C. N. (2010). Spatial and temporal patterns in abundance and distribution of zooplankton in the Tanzanian waters of Lake Victoria. Aquatic Ecosystem Health \& Management, 13(4), 451-457. http://dx.doi.org/10.1080/14634988.2010.525077.

Ngupula, G. W., Mbonde, A. S. E., \& Ezekiel, C. N. (2011). Spatial and temporal patterns of phytoplankton abundance and composition in three ecological zones in the Tanzanian waters of Lake Victoria. African Journal of Aquatic Science, 36(2), 197-206. 
http://dx.doi.org/10.2989/16085914.2011.589118.

Ngupula, G. W., Ezekiel, C. N., Kimirei, I. A., Mboni, E., \& Kashindye, B. B. (2012). Physical and chemical characteristics of the Tanzanian inshore and offshore waters of Lake Victoria in 2005-2008. African Journal of Aquatic Science, 37(3), 339-345. http://dx.doi.org/10.2989/16085914.2012.712503

Nsinda, P. E., Msuku, B. S., \& Mrosso, H. D. (2013). Fishing for Dagaa with $5 \mathrm{~mm}$ and 10 $\mathrm{mm}$ mesh nets: A comparison of length-frequencies and biological characteristics. Aquatic Ecosystem Health \& Management, 16(3), 322-328.doi: 10.1080/14634988.2013.823075,http://dx.doi.org/10.1080/14634988.2013.823075.

Mbahinzireki, G. B. (1994). Initial results of the Benthic fauna studies in the Northern Lake Victoria. In Okemwa E, Getabu A., \& Wakwabi E. (Eds), Proceeding of the 2nd EEC Regional Seminar on Recent Trends of Research on Lake Victoria Fisheries (pp. 7-13). 25-27 $7^{\text {th }}$ Sept, 1991, Kisumu-Kenya. ICIPE Science Press, Nairobi, Kenya. http://oceandocs.org/handle/1834/1351

Ogutu-Ohwayo, R. (1990a). The decline of the native fishes of Lakes Victoria and Kyoga (East Africa) and the impact of introduced species, especially the Nile perch, Lates niloticus and the Nile tilapia, Oreochromis niloticus. Environmental Biology of Fishes, 27, 81-96. http://dx.doi.org/10.1007/BF00001938.

Ogutu-Ohwayo, R. (1990b). Changes in the prey ingested and the variations in the Nile perch and other fish stocks of Lake Kyoga and the northern waters of Lake Victoria (Uganda). Journal of Fish Biology, 37(1), 55-63. http://dx.doi.org/10.1111/j.1095-8649.1990.tb05926.x.

Rzoska, J. (1956). Notes on the crustacean plankton of Lake Victoria. Proceedings of the Limnological Society of London, 168, 116-125.

Ruttner-Kolisko, A. (1974). Plankton rotifers: biology and taxonomy (Vol. 26, p. 146). Schweizerbart. http://dx.doi.org/101-647-560

Sitoki, L., Gichuki, J., Ezekiel, C., Wanda, F., Mkumbo, O. C., \& Marshall, B. E. (2010). The environment of Lake Victoria (East Africa): current status and historical changes. $\begin{array}{llll}\text { International Review of } & \text { Hydrobiology, 95(3), } 223 .\end{array}$ http://dx.doi.org/10.1002/iroh.201011226.

Tumwebaze, R., Cowx, I., Ridgway, S., Getabu, A., \& MacLennan, D. N. (2007). Spatial and temporal changes in the distribution of Rastrineobola argentea in Lake Victoria. Aquatic Ecosystem Health \& Management, 10(4), 398-406. http://dx.doi.org/10.1080/14634980701709527

Wanink, J. H. (1998). Life history tactics of the Lake Victoria sardine Rastrineobola argentea, a survivor of the introduced Nile perch. In: Wanink, J.H. The pelagic cyprinid Rastrineobola argentea as a crucial link in the disrupted ecosystem of Lake Victoria: dwarf and giants-African adventure (pp. 183-193). Netherlands: University of Leiden.

Wanink, J.H, Katunzi, E.F.B, Goudswaard, K.P.C, Witte, F., \& van Densen, W.L.T. (2002). 


\section{Macrothink}

Journal of Environment and Ecology ISSN 2157-6092 2013, Vol. 4, No. 2

The shift to smaller zooplankton in Lake Victoria cannot be attributed to the 'sardine' Rastrineobola argentea (Cyprinidae). Aquatic Living Resources, 15, 37-43. http://dx.doi.org/10.1016/S0990-7440(01)01145-7.

Waya, R. K., \& Mwambungu, J. A. (2004). Zooplankton communities of selected stations of Lake Victoria. Tanzania Journal of Science, 30(1), 11-20. http://dx.doi.org/10.4314/tjs.v30i1.18383.

Witte, F, Wanink J.H, \& Kishe-Machumu, M.A. (2007). Species distinction and the biodiversity crisis in Lake Victoria. Transactions of the American Fisheries Society, 136, 1146-1159. http://dx.doi.org/10.1577/T05-179.1.

Worthington, E.B. (1931). Vertical movements of fresh water macroplankton. Internationale Revue der Gesamte Hydrobiologie und Hydrographie, 25(5-6), 394-436. http://dx.doi.org/10.1002/iroh.19310250510. 